Svetlana KOČOVSKA-STEVOVIḰ

UDK: 821.14'02.09-6

Original research paper

\title{
ANCIENT EPISTOLARY THEORY: A BRIEF OVERVIEW
}

\begin{abstract}
This paper is a brief overview of ancient theoretical views on letters: how the term

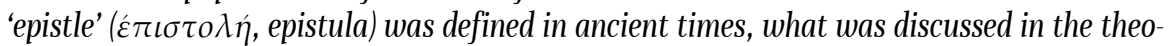
ry of letters, what recommendations comprised epistolary decorum and what types of letters were defined in ancient handbooks of letter-writing. The purpose of the paper is to reconstruct ancient epistolary theory based on surviving evidence. Direct evidence of this the-

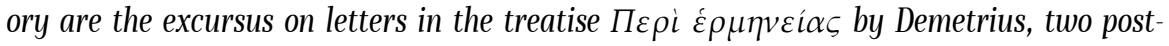

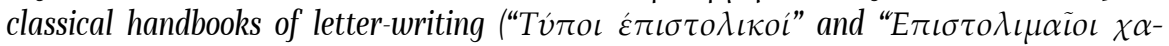
$\rho \alpha \kappa \tau \tilde{\eta} \rho \varepsilon \varsigma$ "), a brief tractate on letters written by the sophist Philostratus of Lemnos, one epistle by Gregory of Nazinanzus and the appendix "De epistulis" at the end of the rhetorical handbook by Gaius Julius Victor "Ars rhetorica". Indirect evidence, on the other hand, of ancient epistolary theory are the not-so-numerous incidental references to letters and letterwriting that are mainly found in Cicero's correspondence.
\end{abstract}

Key words: ANCIENT EPISTOLARY THEORY, ANCIENT LETTER, EPISTOLARY DECORUM

\section{Ancient epistolary theory: direct and indirect evidence}

Ancient epistolographic practice, in its various stages during its long and continuous development, created a production that in terms of the numbers and diversity of letters it contains is difficult to compare with any other later epistolographic production. Although in the Hellenic cultural context this practice was established in as early as the $4^{\text {th }}$ century BC, ${ }^{1}$ the writings that have reached us through manuscript tradition do not give the impression that letters were the subject of extensive theoretical

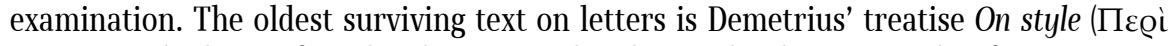

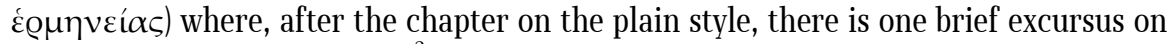
letters (Dem. De eloc. 223-235). ${ }^{2}$ The only surviving handbooks of letter-writing are Let-

\footnotetext{
${ }^{1}$ The oldest preserved letter that contains the epistolary formulas typical for the subsequent epistolographic practice is the letter of Cyrus to Cyaxares, inserted in Xenophon's Cyropaedia (Kú@ov $\pi \alpha \iota \delta \varepsilon i ́ \alpha)$ (Xen. Cyrop. 4.5. 27-33). Cyropaedia was written around 370 BC. The letters that the manuscript tradition assigns to Plato are also dated to this period approximately.

${ }^{2}$ There is no sufficiently credible evidence concerning the author of this work or the time at which it was created. In the latest manuscript (Parisinus Graecus 1741), Demetrius of Phalerum (c.
} 


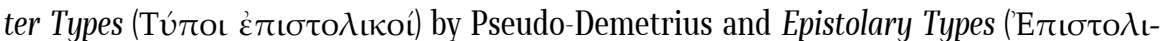
$\mu \alpha \tilde{i o t} \chi \alpha \varrho \alpha \kappa \tau \tilde{\eta} \varrho \varepsilon \varsigma)$ by Pseudo-Libanius ${ }^{3}$, which, as the above mentioned treatise by Demetrius, cannot be precisely dated. ${ }^{4}$ From Pseudo-Demetrius's handbook, which is considered to be older, it is certain that at the time when the handbook was created, there was some theory $(\theta \varepsilon \omega \varrho i ́ \alpha v)$ which dealt with letters. ${ }^{5}$ This theory was probably conceived similarly to the one in Pseudo-Demetrius's work: after the introductory part, which gives some brief recommendations on letters as a form, there was a catalogue with a very short model for various types of letters. In addition to these two works, letters are theoretically reviewed in a short tractate written by the sophist Philostratus (EG: 14-15) and in one letter by Gregory of Nazianzus (ibid. 15-16). The only direct evidence of ancient epistolary theory written in Latin is the appendix On letters (De epistulis), added at the end of Julius Victor's treatise on rhetoric (Ars rhetorica), written in the $4^{\text {th }}$ century AD (RLM pp. 447-8). Apart from this direct evidence, there are some sporadic notes in literature on what a letter is, what types of letters exist and how a letter should be composed. The oldest and most numerous obiter dicta on letters are found in Cicero's letters. Letters are also the subject of some sporadic and brief comments in Seneca's letters (Sen. Ep. 75. 1-4), in Quintilian's handbook The Orator's Education (Institutio oratoria) (Quint. Inst. 1.1.29; 9.4.19-20; 11.1.21) and in two surviving progymnasmata textbooks, ${ }^{6}$ one by the Alexandrian sophist and younger contemporary of Quintilian Ae-

350-280 BC), a peripatetic, student and friend of Theophrastus, is mentioned as its author. In today's theory on this topic there is no dilemma that the author of the treatise is not Demetrius of Phalerum, but it is some other Demetrius or the author is anonymous. The most credible indicator that the well-known peripatetic and student of Theophrastus is not the work's author is the fact that Diogenes Laërtius does not mention this work in the biography of Theophrastus (Diog. Laert. 5. 5), and indicative of this are also the numerous differences in the linguistic expression used in the text and those in the works that were undoubtedly written by Demetrius of Phalerum. The date of the writing is also an open question. The proposed answers cover a period of several centuries, starting from $3^{\text {rd }}$ century BC up to $1^{\text {st }}$ century AD. See for example Innes, 311-335, Kennedy 1994: 88-90.

${ }^{3}$ In some manuscripts, the sophist Libanius is mentioned as the author, while in others - Neoplatonist Proclus. Since it is considered certain that neither of them is the author, it is an accepted convention to refer to the anonymous author as Pseudo-Libanius.

${ }^{4}$ It is assumed that in the period between $2^{\text {nd }}$ century BC and $3^{\text {rd }}$ century AD the text was reissued several times and the text preserved today is a later version of some older text (Poster, 24); the time when the text was written is also uncertain. It is considered that it developed gradually and that the version preserved today was created between the $4^{\text {th }}$ and $5^{\text {th }}$ century AD (Klauck, 202).

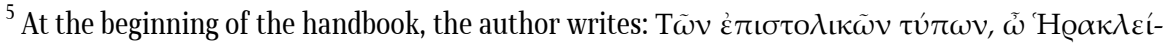

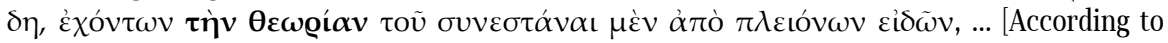
the theory that governs epistolary types, Heraclides, (letters) can be composed in a great number of styles, trans. Malhebre, 31.]

${ }^{6}$ In ancient rhetorical education, the teaching programme known as 'preliminary exercises' $(\pi \varrho 0 \gamma v \mu \nu \alpha ́ \sigma \mu \alpha \tau \alpha)$ comprised fourteen exercises with the aim of preparing future orators, who have just completed their education in grammar, for deeper research into the principles and 
lius Theon ( $R G$ vol. II: p. 115), and the other by Nicolaus Sophista, a teacher of rhetoric in Constantinople from the $5^{\text {th }}$ century AD (Nicolai Progymnasmata: p. 67 ).

Considering that in the surviving handbooks of rhetoric that precede Quintilian's textbook, which is a critical overview of the entire rhetoric theory until then, letters are not mentioned at all and in Quintilian's textbook they are mentioned rarely, it is certain that letters in rhetoric were not of great interest. Recommendations on how to compose letters were not included in the teaching programme known as $\pi 00 \gamma v \mu$ -

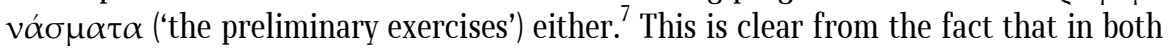
above-mentioned progymnasmata handbooks, letters are discussed only in the exercise

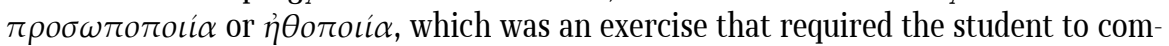
pose a speech or a letter, through which he will present the thoughts of a famous historical figure, a mythological character or an imaginary person. It is likely that in ancient times a letter had the status of a text with a primarily utilitarian function. It was considered that no additional education would be necessary to compose letters, outside of the regular education in grammar and rhetoric. The recommendations on how to compose letters, as Poster believes, were probably in the form of brief notes, handbooks or lectures that the teacher kept from his student days. After that, there was a catalogue of different types of letters which the students used as a model on how to compose a certain type of letter. Writing letters was considered a formulaic process which meant copying parts of the specific model of letter with the necessary minimal corrections (Poster, 22).

\section{On epistolary form (de forma epistolari)}


mon, the editor of Aristotle's letters, quoted by Demetrius in his excursus on letters. According to Artemon, 'the letter is a halved dialogue' (Dem. De eloc. 223). In Pseudo-Libanius' handbook letters are similarly defined: 'A letter, then, is a kind of written con-

techniques of rhetoric. At this level of education, future orators learned how to make up stories

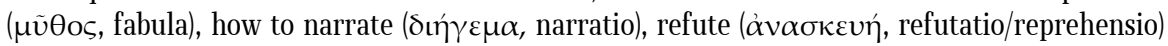

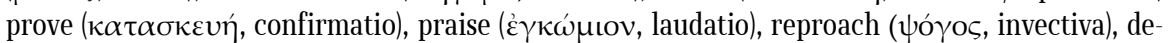

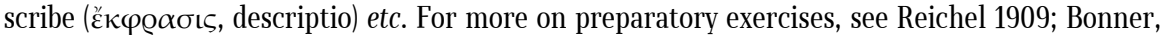
250-276; Kennedy 1983: 54-73; Kennedy 1994: 202-208; Kennedy 1999: 26-28.

${ }^{7}$ The purpose of these exercises was to present more vividly the character of the person chosen to be described. A particular consequence of these exercises are the so-called pseudo-epigraphic letters - a collection of letters of which it is known today that are the work of more recent authors who impersonate popular persons from the past (e.g. Aeschines, Apollonius of Tyana, Aristotle, Euripides, Heraclitus, Pythagoras and Pythagoreans, Socrates etc.), as well as the letters of Alciphron, Aelian and Philostratus, created in the period of the Second Sophistic. The letters of Alciphron, for instance, are letters in which the author impersonates fishermen, country people, parasites, and hetaerae. For pseudepigraphic collections of letters, see, for example, Trapp, 2731, and for the letters of Alciphron ibid. 32-33. 


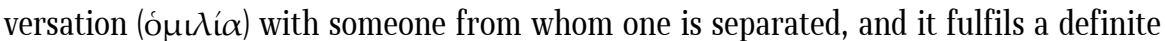
need. One will speak in it as though one were in the company of the absent person' (EG. 6 , trans. Malherbe). It seems that equating letter with conversation was also usual in the theory that preceded the writings of Demetrius and Pseudo-Libanius. This can be concluded from the references to letters and the practice of letter-writing found in $\mathrm{Ci}$ cero. In the Second Philippic, Cicero calls letters amicorum colloquia absentium 'conversation between absent friends' (Cic. Phil. 2.4). The concept that a letter is some kind of a conversation between absent friends, a conversation through a letter or an illusion of a conversation, is a kind of commonplace in Cicero's letters. In a letter to Quintus, for instance, Cicero writes to his brother that he enjoys reading his long letters and that he himself often writes long letters to Quintus, because when he reads the letters he received from him it seems as though he is hearing him (cum tua lego, te audire), while when he is writing letters to him, he feels as if he is talking with him (cum ad te scribo, tecum loqui videor) (Cic. Q. fr. 1.1.45). The impression that a letter is 'a conversation between absent friends' can be noted in the expression loqui cum aliquo absens 'to speak with someone who is absent', which Cicero often uses to describe his practice of writing letters: 'I have not let a day pass so far without sending you some sort of letter, not that I have had a great deal to write about, but just to talk to you in absence [ut loquerer tecum absens]. (Cic. Att. 7.15.1, trans. Shackleton Bailey). ${ }^{8}$

Letters are the subject of the most extensive theoretical elaboration in Demetrius' excursus on composing letters. Out of all four simple styles (oí $\alpha \pi \lambda$ oi $\chi \alpha \varrho \alpha \kappa \tau \tilde{\eta}-$


adequate for letters. The most significant characteristics of the plain style (Dem. De eloc. 190-222), are the use of words in their basic or literal meaning and linking them ade-

\footnotetext{
${ }^{8}$ Identifying a letter with a conversation in absence or an illusion of conversation is particularly common in Cicero's letters and is also found in Seneca's letters. In one letter to Atticus, for example, Cicero asks his recipient to write letters more often, using the expression per litteras colloquare 'to talk with someone through letters': tu velim ... quam saepissime mecum per litteras colloquare 'I hope you will talk to me by letter as often as you can' (Cic. Att. 6.1.24); in another letter he writes that even though he has nothing to write about, he nevertheless decided to write to him a letter because in this way he feels as if he is talking with him: Ego, etsi nihil habeo quod ad te scribam, scribo tamen quia tecum loqui videor 'Although I have nothing to write to you, I write all the same because I feel that I am talking to you.' (Cic. Att. 12.53). See also Cic. Fam. 12.30.1; Fam. 15.14.3; Fam. 15.19.1; Att. 12.39.2; Att. 13.18 etc.). The equation of a letter with conversation can also be glimpsed in Seneca's letters. In one letter he writes to Lucilius that he wants his letters to be written in a language (sermo) that he would use if they were sitting or walking together: 'I prefer that my letters should be just what my conversation would be if you and I were sitting in one another's company or taking walks together, - spontaneous and easy; for my letters have nothing strained or artificial about them.' (Sen. Ep. 75.1, trans. Gummere).

${ }^{9}$ Demetrius defines four simple styles [oi $\alpha \pi \lambda$ oi $\left.\chi \alpha \varrho \alpha \kappa \tau \tilde{\eta} \varrho \varepsilon \varsigma\right]$ : 'the plain' [i $\left.\sigma \chi v o ́ \varsigma\right]$, 'the grand'

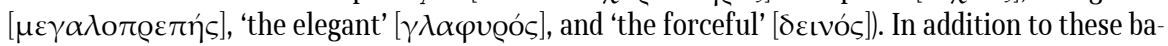
sic styles, according to him, there are other types of styles derived from the mix of the aforementioned ones. See Dem. De eloc. 36-222.
} 
quately in word groups. On the lexical level, the use of compound words, neologisms and ambiguous words is not typical for this style. ${ }^{10}$ On the syntactic level, the plain style has a word sequence that follows the natural course of thoughts, with not very long sentences and without subordinate constructions and rhetorical figures that are not usual for everyday speech. The fact that Demetrius considers 'the style of letters' (o

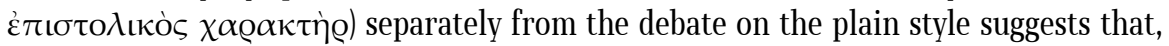
in his opinion, when composing letters it is not sufficient for the author to follow only the recommendations for the plain style. In his review, he compares a letter to a dialogue, epideictic speech and judicial speech. At the beginning of the excursus, he disputes Artemon's thesis that, because a letter is like one of the two sides to a dialogue, it should be written in the same manner as a dialogue. A letter, since it 'is written and sent as a kind of gift' (ibid. 224), in his opinion, should be embellished more carefully than a dialogue, which imitates improvised conversation. The series of abrupt sentence breaks, typical for dialogues, are not considered suitable for a letter, because their presence in writing ( $\dot{\varepsilon} \vee \gamma \varrho \alpha \varphi \tilde{\eta})$, thus in a letter too, would lead to obscurity. The style typical for epideictic and judicial speech is also inadequate for a letter: if someone writes a letter as if it is an epideictic speech, then he would not resemble a man who is chat-

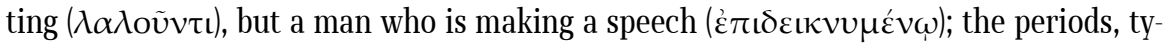
pical for judicial speeches, are also inadequate for a letter, because their presence in

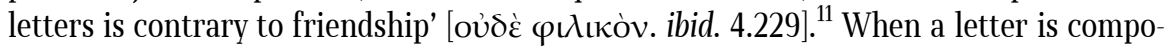
sed, one should have in mind the person to whom a letter is addressed. The style of letters in which the letter-writer addresses cities and kings must be a little more elaborate

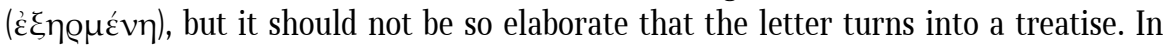
terms of style, Demetrius concludes, the letter should be a mix of two styles - the elegant and the plain (ibid. 235).

The views of other authors are similar to those of Demetrius in many aspects. According to the majority of them, the most adequate for the letter is everyday or colloquial language, which in Demetrius' excursus corresponds to the so-called 'plain style'.

\footnotetext{
${ }^{10}$ A similar position on this issue can also be discerned in Cicero: 'we usually compose letters in ordinary everyday language' [epistulas vero cotidianis verbis texere solemus (Cic. Fam. 9.21.1)].

${ }^{11}$ It is certain from all of this that the primary model of letter on which Demetrius developed his theories was the so-called philophronetic letter - a letter with the primary function of sustaining


dely accepted term philophronetic letter in today's theory is ascribed to Koskenniemi. The English word is a translation of the original term Freundschaftsbrief, created in Koskenniemi's study Studien zur Idee und Phraseologie des griechischen Briefes bis 400 n. Chr. Helsinki: Suomalainen Tiedakatemia, 1956 (non vidi). From the fact that the business letter was not a subject of his interest, it follows that the excursus was mainly meant for the members of Hellenistic aristocracy, who only wrote private letters personally, manu propria or dictated them to a scribe. The writing of business letters was the task of personal secretaries employed in the houses of the aristocracy, who were trained in writing official letters. There probably were special handbooks for their needs, similar to the handbooks by Pseudo-Demetrius and Pseudo-Libanius (Poster, 24).
} 
The most prominent in this respect are the remarks by Gregory of Nazianzus and Julius Victor. Gregory of Nazianzus writes that the one who composes letters should strive towards the "conversational style' ( $\lambda \alpha \lambda_{\iota \kappa}$ òv). In his opinion, 'the best and most beautifully written letter is the one that is persuasive to the uneducated and educated alike, appearing to the former as written on the popular level, and to the latter as above that level, a letter which furthermore is understood at once.' $(E G: 15$, trans. Malherbe). Julius Victor declares that 'Many directives which pertain to oral discourse (de sermone) also apply to letters' (RLM, 447, trans. Malherbe). When he talks about the style of letters he makes a distinction between so-called 'official' (negotiales) and 'personal letters' (familiares). The official letter, in his opinion, should be written similarly to a speech, however not even then one should use all the resources of oratory, because the style of official letters should be closer to conversational style. In private letters, on the other hand, the basic rule that the writer should respect is brevity, however the letter should not be so brief as to leave the impression that something has been omitted. In addition to being adequate to the type of the letter, the style of the letter should also correspond to the type of relation between the letter-writer and the recipient, as well as to the occasion. If the letter is addressed to a person who has a higher position than the letterwriter, it should not be droll; if it is addressed to a person with equal social status, it should not be cold; if it is addressed to a person of lower status, it should not be haughty; if it is addressed to a learned man, it should be carefully composed, however even when it is addressed to an uneducated person, it should be no less cordial. The style of the letter should also be suitable to the occasion itself: when the letter-writer wants to congratulate, the letter should be cordial in order to make the recipient even happier; when the letter comforts a person who is suffering, less words should be used so as not to deepen the recipient's sadness; when the letter-writer is joking, he should have in mind that the circumstances in which the recipient will read the letter might not be appropriate for jokes; when writing a letter of recommendation, the letter-writer should be honest or should not compose the letter at all. The openings and conclusions of letters should conform with the degree of friendship and the recipient's status, and should be written according to the customary epistolary practice.

According to Philostratus and Pseudo-Libanius, the style of the letters should be between everyday speech and the Attic style. Philostratus says that a letter should be written in a language that would be 'more Attic than everyday speech, but more ordinary than Atticism, and it must be composed in accordance with common usage, yet not be at variance with a graceful style.' (EG: 14, trans. Malherbe). Pseudo-Libanius agrees with this view, adding that the letter-writer should 'adorn the letter with excellence of style, and use the Attic style with moderation without, of course, falling into an unbe- 
coming preciousness of speech, for excessive loftiness of speech, verbosity, and Atticism are foreign to the epistolary style, as all of the ancients testify' (ibid. 7). ${ }^{12}$

The majority of ancient epistolary theorists highlight clarity ( $\sigma \alpha \varphi \eta v \varepsilon i \alpha)$ as the most important characteristic of the letter's style. Although Demetrius does not explicitly mention this virtue of style in the context of letters, his position on this topic is obvious. This is evident by the fact that he considers the plain style as the most adequate for the letter, and its main feature is precisely clarity. Secondly, in the section of the excursus, where he talks about the differences between dialogue and letters, he sta-

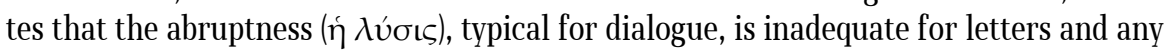
other written forms, because it causes obscurity (Dem. De eloc. 226). Philostratus, Gregory of Nazianzus and Pseudo-Libanius agree with Demetrius that clarity should be the characteristic of any written form, particularly of letters. Philostratus, for instance, declares that: 'While clarity is a good guide for all discourse, it is especially so for a letter.' (EG: 14, trans. Malherbe). According to Gregory of Nazianzus, the best letter is one 'which furthermore is understood at once, for it were as inopportune that a riddle be seen through (at once) as that a letter be in need of interpretation' (ibid. 15). Julius Victor also believes that all types of letters should have clarity. The use of secret codes is allowed only in letters containing sensitive information, however they should also be understandable and clear to the intended recipients. When there is no need for secrecy, obscurity should be avoided, even more than in speech and conversation, because the physical separation between the participants in the correspondence means inability to ask for additional explanation from the other correspondent (RLM: 448).

Other topics that are present in ancient epistolary theory are the length of the letter and epistolary themes. The length of the letter, according to Demetrius, should be moderate, because if letters are too long, then they will not look like letters but like discussions with epistolary formulae inserted (Dem. De eloc. 228). Yet, letters should not be so brief as to leave the impression that something has been omitted (RLM: 447). In terms of this question, Gregory of Nazianzus thinks that there are no strict rules, because the length of the letter should conform to the need the letter aims to meet: if there is not much to say about the topic, then the letter should be brief, while if there are many things to be said on the subject, then the letter-writer should not skimp on words (EG: 15). Demetrius considers that problems of logic or natural philosophy are inadequate for a letter. In his opinion, the letter-writer should choose simple topics that would be expressed briefly and with simple words.

\footnotetext{
${ }^{12}$ The statement 'as all of the ancients testify' [ $\tilde{\omega} \varsigma \pi \alpha \dot{\alpha} \tau \tau \varepsilon \varsigma$ oi $\pi \alpha \lambda \alpha$ เoì $\left.\mu \alpha \varrho \tau v \varrho o v \sigma \sigma\right]$ in this quote clearly suggests that the views which Pseudo-Libanius describes in his debate were typical for epistolary theory that preceded his writing.
} 


\section{Types of letters (genera epistularum)}

The two surviving texts which devote considerable attention to the typology of letters, those by Pseudo-Demetrius and Pseudo-Libanius, date from the post-classical period. The only confirmed theoretical views from the classical period on this topic are the not so numerous remarks about the types of letters in Cicero's letters. Since Cicero's remarks are the oldest, they will be discussed first in this brief overview.

The most general division of letters into 'public' (litterae publicae) and 'private (litterae privatae) is found in Cicero's speech For Flaccus (Cic. Flac. 37). That this division was not the only one in Cicero's time can be seen in Ad Familiares 2. 4. 1, where Cicero mentions to Curio three types of letters: (1) 'to inform the absent of anything that is to the interest of the writer or recipient that they should know' [ut certiores faceremus absentis si quid esset quod eos scire aut nostra aut ipsorum interesset], (2) 'the familiar and sportive' [familiare et iocosum (sc. genus epistularum)], and (3) 'the grave and serious' [severum et grave] (Cic. Fam. 2. 4. 1). Most frequent were probably the letters of the first type, for which, as Cicero remarks, the practice of composing letters was invented. The terms denoting the two other mentioned letter types allude to their fundamental properties: the second type, 'the familiar and sportive', certainly referred to the letters of a less formal character addressed to close friends, while the third type, 'the grave and serious letter', referred to the letters to not so close recipients discussing more serious topics. In Cicero's correspondence there are mentions of other types of letters. In one letter, Cicero writes to Antonius (Cic. Fam. 5.5.1) that he is breaking his own decision to write to him only 'letters of recommendation' (commendaticias). ${ }^{13}$ It seems that the socalled consolationes 'consolation letters' (ibid. 4. 13.1) and gratulationes 'congratulation letters' (ibid. 2. 7. 1) were quite well-established types of letters. The function of the former was to console someone for something (consolari aliquem in aliqua re), and of the latter - to congratulate someone on something (gratulari alicui de aliqua re). The terms that Cicero uses to denote all of the aforementioned types, as seen further on, resemble some of the terms denoting types of letters in the typologies of Pseudo-Demetrius and Pseudo-Libanius.

In Pseudo-Demetrius' classification there are 21 types of letters, while in the classification of Pseudo-Libanius almost double that number - 41 types. Twelve types are identical in both classifications:

\footnotetext{
${ }^{13}$ In these letters, the letter-writer, calling upon his own integrity and the friendship with the recipient, asked the addressee to accept someone in amicitiam or to make a specific favour to a third person. In addition to Cicero's letters of recommendation (Ad Familiares, book 13), around twenty letters of recommendation by Pliny were preserved (see Sherwin-White, 12-3) and sixteen by Fronto (see Van den Hout, 399).
} 


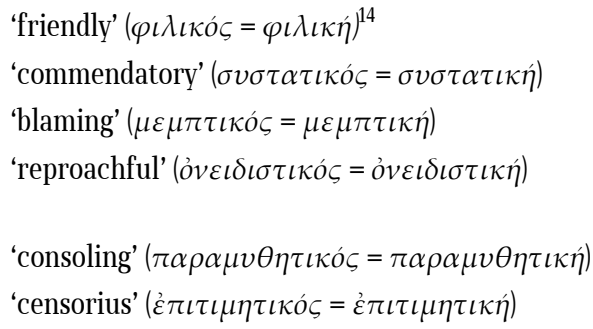

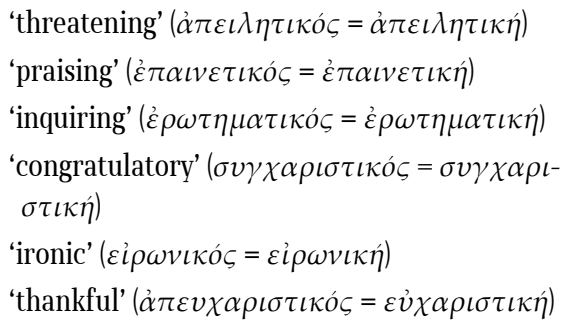

In Pseudo-Demetrius' classification, in addition to the above, the following nine types of letters are mentioned:

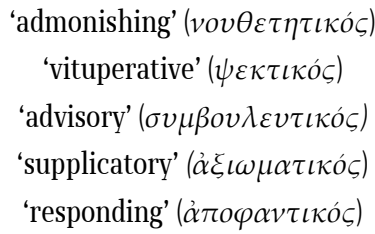

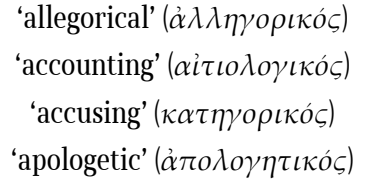

The remaining 29 types of letters in Pseudo-Libanius' classification are the following:



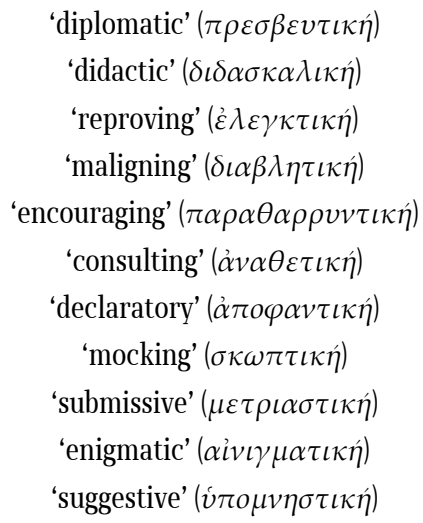

\footnotetext{
${ }^{14}$ In the typology of Pseudo-Demetrius, letters are marked with a masculine adjective, which has

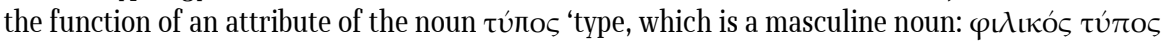
'friendly type [of letter]'; in the typology of Pseudo-Libanius the adjective for each type of letter is

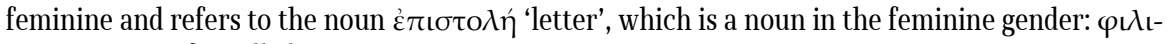
$\kappa \eta \dot{~ \varepsilon ̇ \tau ı \sigma \tau о \lambda \eta ் ~ ' f r i e n d l y ~ l e t t e r ' . ~}$
} 


\section{References}

Aristotle. (1995). Poetics, Longinus: On the sublime, Demetrius: On style. edited and translated by Stephen Halliwell, Donald Russell and Doreen C. Innes, Cambridge, MA: Harvard University Press, London, EN: Cambridge.

Bonner, S. F. (1977). Education in Ancient Rome: from the Elder Cato to the Younger Pliny. London and New York: Routledge Taylor \& Francis Group.

Cicero (1965-67). Cicero's letters to Atticus. edited and translated by D. R. Shackleton Bailey, vols. 1-6, Cambridge: Cambridge University Press.

Cicero (1977). Epistulae ad familiares. edited by D. R. Shackleton Bailey, vols. 1-2. Cambridge: Cambridge University Press.

Cicero (1977). Orations: In Catilinam 1-4, Pro Murena, Pro Sulla. Pro Flacco. with an English translation by C. MacDonald, Cambridge, MA: Harvard University Press, London: W. Heinemann.

Cicero. (2004). Epistulae ad Quintum fratrem et M. Brutum. edited by D. R. Shackleton Bailey. Cambridge: Cambridge University Press.

Деметриј. (2016). За јазичниой израз. Превод од старогрчки јазик, предговор, белешки, коментари и индекс на поими Весна Томовска. Скопје: Три.

EG = Epistolographi Graeci (1873). ed. Rudolphus Hercher. Parisiis: Editore Ambrosio Firmin Didot.

Hout, M. van den. (1999). A Commentary on the Letters of M. Cornelius Fronto. Mnemosyne Supplement 190. Leiden: E. J. Brill.

Innes, D. C. (1995). "Introduction" in Aristotle, Poetics, Longinus, On the sublime, Demetrius on style. edited and translated by Stephen Halliwell, Donald Russell and Doreen C. Innes, Cambridge, MA and London EN: Harvard University Press, pp. 311-342.

Kennedy, G. A. (1983). Greek Rhetoric Under Christian Emperors. Princeton, New Jersey: Princeton University Press.

Kennedy, G. A. (1994). A New History of Classical Rhetoric. Princeton, New Jersey: Princeton University Press.

Kennedy, G. A. (1999). Classical Rhetoric and its Christian and Secular Tradition from Ancient to Modern Times. Chapel Hill and London: The University of North Carolina Press.

Klauck, H. (2006). Ancient letters and the New Testament. Waco: Baylor University Press.

Koskenniemi H. (1954). "Cicero über die Briefarten (genera epistularum)” Arctos I: Acta Philologica Fennica, Nova Series. Vol. 1. 1954, pp. 97-102. (non vidi)

Malherbe A. J. (1988). Ancient epistolary theorists. Atlanata: Scholars Press.

Nicolaus Sophista (1913). Nicolai Progymnasmata, ed. Josephus Felten. Lipsiae: In Aedibus B. G. Teubneri. 
Poster, C. (2007). "A conversation Halved: Epistolary Theory in Graeco-Roman Antiquity" in Letter-writing Manuals and Instruction from Antiquity to the Present. C. Poster and L. C. Mitchell (eds.). Columbia, SC: University of South Carolina Press, pp. 21-51.

Quintilian (2002). The Orator's Education. vols. 1-5, edited and translated by Donald A. Russel, Cambridge, MA: Harvard University Press.

Reichel, G. (1909). Quaestiones progymnasmaticae. Leipzig: Typis Roberti Noske Bornensis.

$R G=$ Rhetores Graeci (1854). (vol. II). ed. Leonardus Spengel. Lispiae: Sumptibus et typis B. G. Teubneri.

RLM = Rhetores Latini Minores. (1863). ed. Carolus Halm, Lipsiae in aedibus B. G. Teubneri.

Seneca (1920). Epistles, vol. 2 (epistles 66-92). translated by Richard M. Gummere. Cambridge, MA: Harvard University Press, London: William Heinemann, Ltd.

Sherwin-White, A. N. (1966). The Letters of Pliny: A History and Social Commentary. Oxford: Oxford University Press.

Trapp, M. B. (2003). Greek and Latin Letters. Cambridge: Cambridge University Press.

Xenophon (1914). Cyropaedia. vol. 1, translated by Walter Miller, Cambridge, MA: Harvard University Press, London: William Heinemann, Ltd. 